\title{
MAGNESIUM METABOLISM IN HEALTH AND DISEASE. II. THE EFFECT OF THE PARATHYROID HORMONE
}

\author{
By DOROTHY M. TIBBETTS AND JOSEPH C. AUB \\ (From the Medical Laboratories of the Collis P. Huntington Memorial Hospital of Harvard \\ University, Boston)
}

(Received for publication December 22, 1936)

In this series of studies of the relationship between calcium, magnesium, and phosphorus exchange, the effect of the parathyroid hormone is obviously of primary interest. With the dramatic changes which occur in calcium metabolism, it might be anticipated that similar effects would be found in magnesium exchange, and that this might be evident in soft tissue as well as bone metabolism.

Greenwald and Gross (1) found that thyroparathyroidectomy in dogs had practically no effect on magnesium excretion. A potent parathyroid extract, however, increased fecal magnesium but had no effect on the urinary excretion (2). After most of the data here recorded had been accumulated, there appeared a publication by Bulger and Gausmann (3), who stated that a loss of calcium is accompanied by a loss of magnesium in hyperparathyroidism and that retention of both accompanies postoperative recovery.

Our data differ somewhat from these observations in untreated hyperparathyroidism. The total magnesium excretion in our three cases of parathyroid adenoma showed no great loss of magnesium. The balances varied; in only one case (G. M.) was there a negative balance, the other two showing a greater storage of magnesium than did our normal controls on a similar intake (4).

However, when comparing the excretion in the same individual before and after parathyroidectomy we find that variations in magnesium do occur, as reported by Bulger and Gausmann (3). These variations are in the same direction though not of the same magnitude as the large changes in calcium excretion.

The observations here reported were all made on patients on the same regime and approximately the same diets as our normal controls described in Paper I of this series (4). The same methods of analysis were also used. The case histories are appended. ${ }^{1}$

Patient G. M. (Table I), a boy of 13 , was in a serious toxic state because of an intensely overactive parathyroid adenoma. This condition was entirely relieved by operation. Very careful metabolic observations were made upon him before and promptly after the complete removal of his 11.8 gram parathyroid adenoma. A third observation on exactly the same routine was obtained three months after the operation. These studies were made with both high and low calcium diets in order to observe variations in absorption and excretion which these changes might produce, but no clear cut variation in magnesium metabolism was obvious. The slight changes in excretion were those to be anticipated from the increased magnesium ingestion necessitated by the change in diet.

It is readily seen that immediately after operation there is a marked fall in urinary magnesium excretion and a less dramatic drop in the fecal magnesium. These changes, however, had partly disappeared three months after the operation, though the storage of calcium was then most dramatic. The variations of magnesium metabolism must be interpreted with due regard to changes in weight. Thus, during the pre-operative periods ( $\mathrm{I}$ to $\mathrm{V}$ ) and in the observation three months after his operation (XI to XV) his weight was stationary, while he was gaining much weight during the periods immediately after operation. The amount of soft tissue magnesium involved, as well as that which should accompany calcium storage in bone can be roughly calculated. The definite diminution of magnesium excretion in the first postoperative periods is not comparable to the dramatic total change in the calcium balance but is more than ten times as great as the amount to be expected from the calcium balance if the ratio in (5).

1 These patients are also discussed in another paper 
TABLE I

Patient G. M., No. 32-599. Parathyroid adenoma

(Intake and output in 3-day periods)

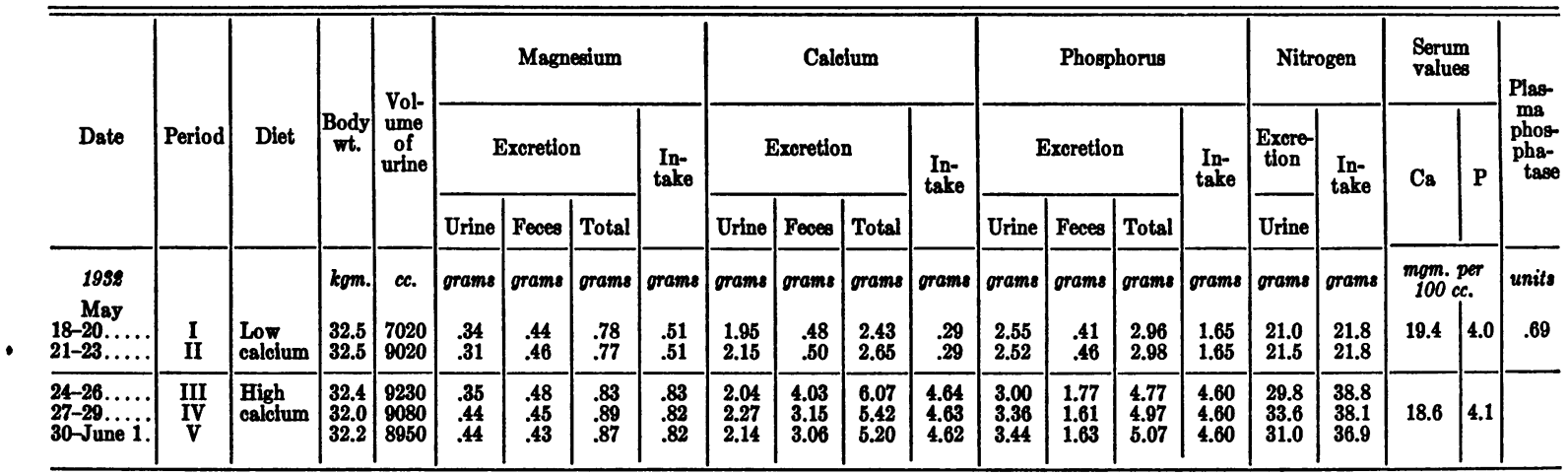

PARATHYROIDNCTOMY-JUNR 4, 1932

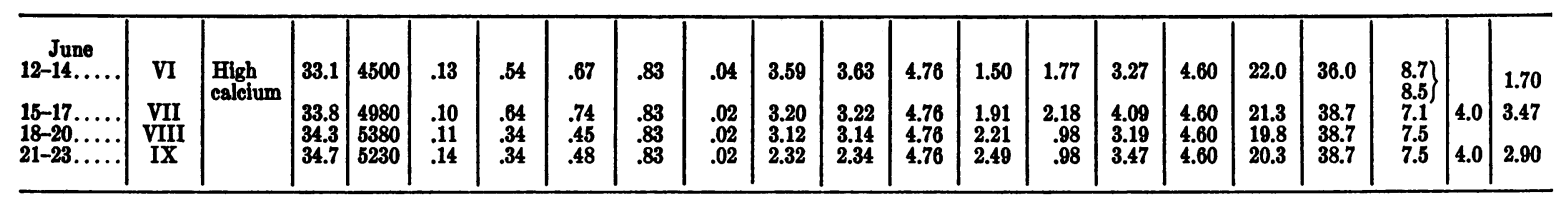

BECOND ADYISBION-BEPTEMBER 8, 1932

\begin{tabular}{|c|c|c|c|c|c|c|c|c|c|c|c|c|c|c|c|c|c|c|c|c|c|}
\hline $\begin{array}{l}\text { September } \\
14-16 \ldots \ldots \\
17-19 . \ldots\end{array}$ & $\underset{\text { XII }}{\text { XI }}$ & $\begin{array}{l}\text { High } \\
\text { calcium }\end{array}$ & $\begin{array}{l}40.7 \\
40.7\end{array}$ & $\begin{array}{l}5300 \\
4980\end{array}$ & $\begin{array}{l}.36 \\
.35\end{array}$ & $\begin{array}{l}.42 \\
.44\end{array}$ & $\begin{array}{l}.78 \\
.79\end{array}$ & $\begin{array}{l}.83 \\
.83\end{array}$ & $\begin{array}{l}.02 \\
.02\end{array}$ & $\begin{array}{l}1.60 \\
1.67\end{array}$ & $\begin{array}{l}1.62 \\
1.69\end{array}$ & $\begin{array}{l}4.76 \\
4.76\end{array}$ & $\begin{array}{l}2.60 \\
2.74\end{array}$ & $\begin{array}{l}.61 \\
.65\end{array}$ & $\begin{array}{l}3.21 \\
3.39\end{array}$ & $\begin{array}{l}4.60 \\
4.60\end{array}$ & $\begin{array}{l}30.8 \\
30.8\end{array}$ & $\begin{array}{l}38.7 \\
38.7\end{array}$ & $\begin{array}{l}10.4 \\
10.4\end{array}$ & \begin{tabular}{|l|}
5.2 \\
6.1
\end{tabular} & 1.51 \\
\hline $\begin{array}{l}20-22 \ldots \ldots \\
23-25 . \ldots \ldots \\
26-28 . \ldots\end{array}$ & $\underset{\mathbf{X I V}}{\mathbf{X I I}}$ & $\begin{array}{l}\text { Low } \\
\text { calcium }\end{array}$ & $\begin{array}{l}40.1 \\
40.6 \\
40.6\end{array}$ & $\begin{array}{l}3840 \\
3490 \\
4040\end{array}$ & $\begin{array}{l}.23 \\
.22 \\
.22\end{array}$ & $\begin{array}{l}.21 \\
.20 \\
.30\end{array}$ & $\begin{array}{l}.44 \\
.42 \\
.52\end{array}$ & $\begin{array}{l}.51 \\
.51 \\
.51\end{array}$ & $\begin{array}{l}.02 \\
.01 \\
.01\end{array}$ & $\begin{array}{l}.10 \\
.11 \\
.09\end{array}$ & $\begin{array}{l}.12 \\
.12 \\
.10\end{array}$ & $\begin{array}{l}.29 \\
.29 \\
.29\end{array}$ & $\begin{array}{l}1.69 \\
1.67 \\
1.21\end{array}$ & $\begin{array}{l}.25 \\
.33 \\
.30\end{array}$ & $\begin{array}{l}1.94 \\
2.00 \\
1.51\end{array}$ & $\begin{array}{l}1.65 \\
1.65 \\
1.65\end{array}$ & $\begin{array}{l}19.2 \\
15.7 \\
15.9\end{array}$ & $\begin{array}{l}21.8 \\
21.8 \\
21.8\end{array}$ & 9.7 & & \\
\hline $\begin{array}{c}29-31 \ldots . . \\
\text { Ootober } \\
1-3 . \ldots \ldots \ldots \\
4-6 . \ldots \ldots\end{array}$ & $\begin{array}{c}\text { XVI } \\
\text { XVII } \\
\text { XVII }\end{array}$ & \begin{tabular}{|l|} 
High \\
caloium \\
plus \\
viosterol
\end{tabular} & & $\begin{array}{l}5040 \\
5440 \\
4940\end{array}$ & $\begin{array}{l}.28 \\
.32 \\
.30\end{array}$ & $\begin{array}{l}.40 \\
.36 \\
.33\end{array}$ & $\begin{array}{l}.68 \\
.68 \\
.63\end{array}$ & $\begin{array}{l}.83 \\
.83 \\
.83\end{array}$ & $\begin{array}{l}.01 \\
.04 \\
.02\end{array}$ & $\begin{array}{l}1.42 \\
1.62 \\
1.68\end{array}$ & $\begin{array}{l}1.43 \\
1.66 \\
1.70\end{array}$ & $\begin{array}{l}4.76 \\
4.76 \\
4.76\end{array}$ & $\begin{array}{l}1.93 \\
2.62 \\
2.26\end{array}$ & $\begin{array}{l}.70 \\
.71 \\
.70\end{array}$ & $\begin{array}{l}2.63 \\
\\
3.33 \\
2.96\end{array}$ & $\begin{array}{l}4.60 \\
4.60 \\
4.60\end{array}$ & $\begin{array}{l}26.4 \\
31.6 \\
27.0\end{array}$ & $\begin{array}{l}\mathbf{3 8 . 7} \\
\\
\mathbf{3 8 . 7} \\
\mathbf{3 8 . 7}\end{array}$ & $\begin{array}{l}10.9 \\
10.5\end{array}$ & 6.0 & $\begin{array}{l}.92 \\
.83\end{array}$ \\
\hline
\end{tabular}

bones is taken to be $\mathrm{Ca}: \mathrm{Mg}=100: 1$. It seems, therefore, justifiable to assume that soft tissue magnesium is involved in the phenomenon. If one assumes a concentration of $20 \mathrm{mgm}$. per cent of magnesium in soft tissues, the average gain of 400 grams in weight in the first postoperative periods represents $80 \mathrm{mgm}$. of magnesium which should be stored in each of these four periods. The amount of calcium stored during this time averages 1.68 grams per period, or, at the bone ratio of $100: 1,17 \mathrm{mgm}$. of magnesium. The sum of these rough approximations-about 100 mgm.-is still less than half the actual average gain in magnesium (245 mgm. per period). Therefore, there was a striking storage of magnesium immediately after correction of this hyperparathyroidism. The observation suggests that much of this reduction is dependent upon soft tissue rather than bone exchange. Three months later, when calcium retention was increased in intensity, the magnesium excretion still showed a lower level than before operation, though not of great magnitude. This influence is more obvious during the periods of low calcium and magnesium diet, where both urinary and fecal excretion are still reduced. Part of this retention still appears to involve soft tissue magnesium. Here, then, the metabolic exchanges do run parallel, but the calcium retention is of greater intensity and of longer duration.

Patient A. R. (Table II), was a woman of 44 years, who had mild symptoms from a parathyroid adenoma, relieved by operation. At her first admission, following $x$-ray-induced menopause, she showed a nearly normal serum calcium level. During the second observation, six months later, the metabolic evidence definitely indicated parathyroid overactivity. The third study was made six weeks following a successful removal of a small parathyroid adenoma. 
TABLE II

Patient A. R., No. 32-291. Parathyroid adenoma

(Intake and output in 3-day periods)

\begin{tabular}{|c|c|c|c|c|c|c|c|c|c|c|c|c|c|c|c|c|c|c|c|c|c|}
\hline \multirow{3}{*}{ Dato } & \multirow{3}{*}{ Period } & \multirow{3}{*}{ Diet } & \multirow{3}{*}{$\begin{array}{c}\text { Body } \\
\text { wt. }\end{array}$} & \multicolumn{4}{|c|}{ Magnesium } & \multicolumn{4}{|c|}{ Calcium } & \multicolumn{4}{|c|}{ Phosphorus } & \multicolumn{2}{|c|}{ Nitrogen } & \multicolumn{3}{|c|}{$\begin{array}{l}\text { Serum values } \\
\text { (fasting) }\end{array}$} & \multirow{3}{*}{$\begin{array}{l}\text { Plas- } \\
\text { ma } \\
\text { phos } \\
\text { pha- } \\
\text { tase }\end{array}$} \\
\hline & & & & \multicolumn{3}{|c|}{ Excretion } & \multirow{2}{*}{$\underset{\text { take }}{\text { In- }}$} & \multicolumn{3}{|c|}{ Excretion } & \multirow{2}{*}{$\underset{\text { take }}{\text { In- }}$} & \multicolumn{3}{|c|}{ Excretion } & \multirow{2}{*}{$\underset{\text { take }}{\text { In- }}$} & $\begin{array}{c}\text { Excre- } \\
\text { tion }\end{array}$ & & & & & \\
\hline & & & & Urine & Feces & Total & & Urine & Feces & Total & & Urine & Feces & Total & & Urine & & & & & \\
\hline $\begin{array}{c}1938 \\
\text { April } \\
5-7 \ldots \ldots \ldots \\
8-10 \ldots \ldots \ldots \\
11-13 . \ldots \ldots \ldots\end{array}$ & III & $\begin{array}{l}\text { High } \\
\text { calcium }\end{array}$ & \begin{tabular}{|l|} 
kom. \\
\\
83.2 \\
83.2 \\
83.7
\end{tabular} & $\begin{array}{l}\text { grams } \\
.25 \\
.27 \\
.25\end{array}$ & \begin{tabular}{c|} 
grams \\
\\
.40 \\
.45 \\
.51
\end{tabular} & \begin{tabular}{r|} 
grams \\
\\
.65 \\
.72 \\
.76
\end{tabular} & $\begin{array}{l}\text { orams } \\
.93 \\
.93 \\
.93\end{array}$ & $\begin{array}{r}\text { orams } \\
.99 \\
1.00 \\
.92\end{array}$ & $\begin{array}{l}\text { grams } \\
\\
2.38 \\
2.10 \\
1.90\end{array}$ & $\begin{array}{l}\text { grams } \\
\\
3.37 \\
3.10 \\
2.82\end{array}$ & $\begin{array}{l}\text { grams } \\
\\
5.84 \\
5.84 \\
5.84\end{array}$ & $\begin{array}{l}\text { grams } \\
\\
3.90 \\
4.10 \\
4.16\end{array}$ & \begin{tabular}{|l|} 
grams \\
\\
1.21 \\
1.17 \\
1.08
\end{tabular} & $\begin{array}{l}\text { grams } \\
\\
5.11 \\
5.27 \\
5.24\end{array}$ & $\begin{array}{l}\text { grams } \\
\\
6.43 \\
6.43 \\
6.43\end{array}$ & grams & grams & & $\begin{array}{l}\text { m. per } \\
0 \text { cc. } \\
10.7 \\
11.2\end{array}$ & 1.7 & units \\
\hline
\end{tabular}

BECOND ADMISSION-OCTOBER 17, 1932

\begin{tabular}{|c|c|c|c|c|c|c|c|c|c|c|c|c|c|c|c|c|c|c|c|c|c|}
\hline $\begin{array}{c}\text { Ootober } \\
21-23 \ldots \ldots \ldots \\
24-26 \ldots \ldots \ldots\end{array}$ & $\begin{array}{l}\text { VI } \\
\text { VII }\end{array}$ & $\begin{array}{l}\text { Low } \\
\text { calcium }\end{array}$ & $\begin{array}{l}84.1 \\
84.1\end{array}$ & $\begin{array}{l}.25 \\
.26\end{array}$ & $\begin{array}{l}.20 \\
.23\end{array}$ & $\begin{array}{l}.45 \\
.49\end{array}$ & $\begin{array}{l}.51 \\
.51\end{array}$ & $\begin{array}{l}.62 \\
.75\end{array}$ & $\begin{array}{l}.12 \\
.13\end{array}$ & $\begin{array}{l}.74 \\
.88\end{array}$ & $\begin{array}{l}.29 \\
.29\end{array}$ & $\begin{array}{l}1.93 \\
1.74\end{array}$ & $\begin{array}{l}.41 \\
.49\end{array}$ & $\begin{array}{l}2.34 \\
2.23\end{array}$ & $\begin{array}{l}1.65 \\
1.65\end{array}$ & $\begin{array}{l}20.6 \\
20.5\end{array}$ & $\begin{array}{l}21.8 \\
21.8\end{array}$ & & 13.6 & 2.5 & 1.36 \\
\hline $\begin{array}{l}\text { 30-Novem- } \\
\text { ber } 1 \ldots \ldots \ldots \\
2-4 \ldots \ldots \ldots \ldots \\
5-7 \ldots \ldots \ldots \ldots\end{array}$ & $\underset{\mathbf{X I}}{\mathbf{I X}}$ & $\begin{array}{l}\text { High } \\
\text { calcium }\end{array}$ & \begin{tabular}{|l|}
84.4 \\
84.2 \\
83.6
\end{tabular} & $\begin{array}{l}.32 \\
.38 \\
.37\end{array}$ & $\begin{array}{l}.29 \\
.44 \\
.43\end{array}$ & $\begin{array}{l}.61 \\
.82 \\
.80\end{array}$ & $\begin{array}{l}.93 \\
.93 \\
.93\end{array}$ & $\begin{array}{l}1.93 \\
2.10 \\
2.08\end{array}$ & $\begin{array}{r}.60 \\
1.06 \\
1.08\end{array}$ & $\begin{array}{l}2.59 \\
3.16 \\
3.16\end{array}$ & $\begin{array}{l}5.84 \\
5.84 \\
5.84\end{array}$ & $\begin{array}{l}3.71 \\
3.78 \\
4.20\end{array}$ & $\begin{array}{l}.58 \\
.74 \\
.70\end{array}$ & $\begin{array}{l}4.29 \\
4.52 \\
4.90\end{array}$ & $\begin{array}{l}6.44 \\
6.44 \\
6.44\end{array}$ & $\begin{array}{l}51.5 \\
49.6 \\
51.0\end{array}$ & $\begin{array}{l}58.5 \\
58.5 \\
58.5\end{array}$ & $\begin{array}{l}3.1 \\
2.8\end{array}$ & \begin{tabular}{|l|}
13.0 \\
13.6
\end{tabular} & 3.4 & $\begin{array}{c}1.080 \\
.0\end{array}$ \\
\hline
\end{tabular}

PARATHYROIDECTOYT-DECHMBER 2, 1932

THIRD ADMISGION-JANOABT 18, 1933

\begin{tabular}{|c|c|c|c|c|c|c|c|c|c|c|c|c|c|c|c|c|c|c|c|c|}
\hline $\begin{array}{c}198 s \\
\text { January } \\
26-28 \ldots \ldots \ldots \\
29-31 . \ldots \ldots \ldots\end{array}$ & $\underset{\mathbf{X I V}}{\mathbf{X I I I}}$ & $\begin{array}{l}\text { Low } \\
\text { calcium }\end{array}$ & $\begin{array}{l}83.9 \\
83.4\end{array}$ & $\begin{array}{l}.15 \\
.21\end{array}$ & $\begin{array}{l}.36 \\
.22\end{array}$ & $\begin{array}{l}.51 \\
.43\end{array}$ & $\begin{array}{l}.51 \\
.51\end{array}$ & $\begin{array}{l}.02 \\
.02\end{array}$ & $\begin{array}{l}.30 \\
.19\end{array}$ & $\begin{array}{l}.32 \\
.21\end{array}$ & $\begin{array}{l}.29 \\
.29\end{array}$ & $\begin{array}{l}1.55 \\
1.59\end{array}$ & $\begin{array}{l}.69 \\
.43\end{array}$ & $\begin{array}{l}2.24 \\
2.02\end{array}$ & $\begin{array}{l}1.65 \\
1.65\end{array}$ & $\begin{array}{l}19.6 \\
19.0\end{array}$ & $\begin{array}{l}21.8 \\
21.8\end{array}$ & $\begin{array}{l}9.8 \\
9.9\end{array}$ & 3.9 & $\begin{array}{l}.50 \\
.55\end{array}$ \\
\hline $\begin{array}{l}\text { February } \\
\text { 5-7 } \ldots \ldots \ldots \ldots \\
8-10 \ldots \ldots \cdots \cdots\end{array}$ & $\underset{\text { XVII }}{\text { XVI }}$ & $\begin{array}{l}\text { High } \\
\text { calcium }\end{array}$ & $\begin{array}{l}83.2 \\
83.0\end{array}$ & $\begin{array}{l}.25 \\
.34\end{array}$ & $\begin{array}{l}.39 \\
.46\end{array}$ & $\begin{array}{l}.64 \\
.80\end{array}$ & $\begin{array}{l}.93 \\
.93\end{array}$ & $\begin{array}{l}.13 \\
.19\end{array}$ & $\begin{array}{l}2.08 \\
2.92\end{array}$ & $\begin{array}{l}2.21 \\
3.11\end{array}$ & $\begin{array}{l}5.84 \\
5.84\end{array}$ & $\begin{array}{l}3.44 \\
3.50\end{array}$ & $\begin{array}{r}.91 \\
1.20\end{array}$ & $\begin{array}{l}4.35 \\
4.70\end{array}$ & $\begin{array}{l}6.44 \\
6.44\end{array}$ & $\begin{array}{l}57.4 \\
48.7\end{array}$ & $\begin{array}{l}\mathbf{5 8 . 5} \\
\mathbf{5 8 . 5}\end{array}$ & 9.8 & 4.2 & .56 \\
\hline
\end{tabular}

The data accumulated during the second observation, therefore, represents the period of parathyroid overactivity. The urinary figures indicate a somewhat larger magnesium excretion than in either the first or the third study, just as occurred with the urinary calcium, but the total output of magnesium in the three observations remained the same. In this patient there was a definite storage of magnesium during and after the hyperparathyroid state and the change from a low calcium and phosphorus diet to one very high in both of these constituents had little if any effect on the magnesium metabolism. If the removal of the parathyroid adenoma had any effect upon the magnesium balance, it was not obvious two months after the operation except in regard to the proportion excreted in the urine.

$E$. $M$. was a normal male control of 64 years, who had had a severe lead colic three months before the observation. Kept on a constant diet (except for a slight change after the fourth pe- riod), he received parathyroid extract ${ }^{2}$ (Lilly) as indicated in Table III.

The effect on the calcium metabolism was typical and of large proportions. The effect on magnesium exchange certainly was not large, although there was an increase in urinary excretion in Periods IV and V which is more than can be accounted for by the increased calcium excretion from the bones. This elevation was not constant, however, and returned to the control level in the last period, while calcium elimination remained high.

\section{Can magnesium substitute for calcium in the body?}

Inasmuch as magnesium has apparently often mimicked in small degree the calcium changes which follow acidosis (4) and parathyroid stimu-

2 We are indebted to Eli Lilly Co. for this parathyroid extract. 
DOROTHY M. TIBBETTS AND JOSEPH C. AUB

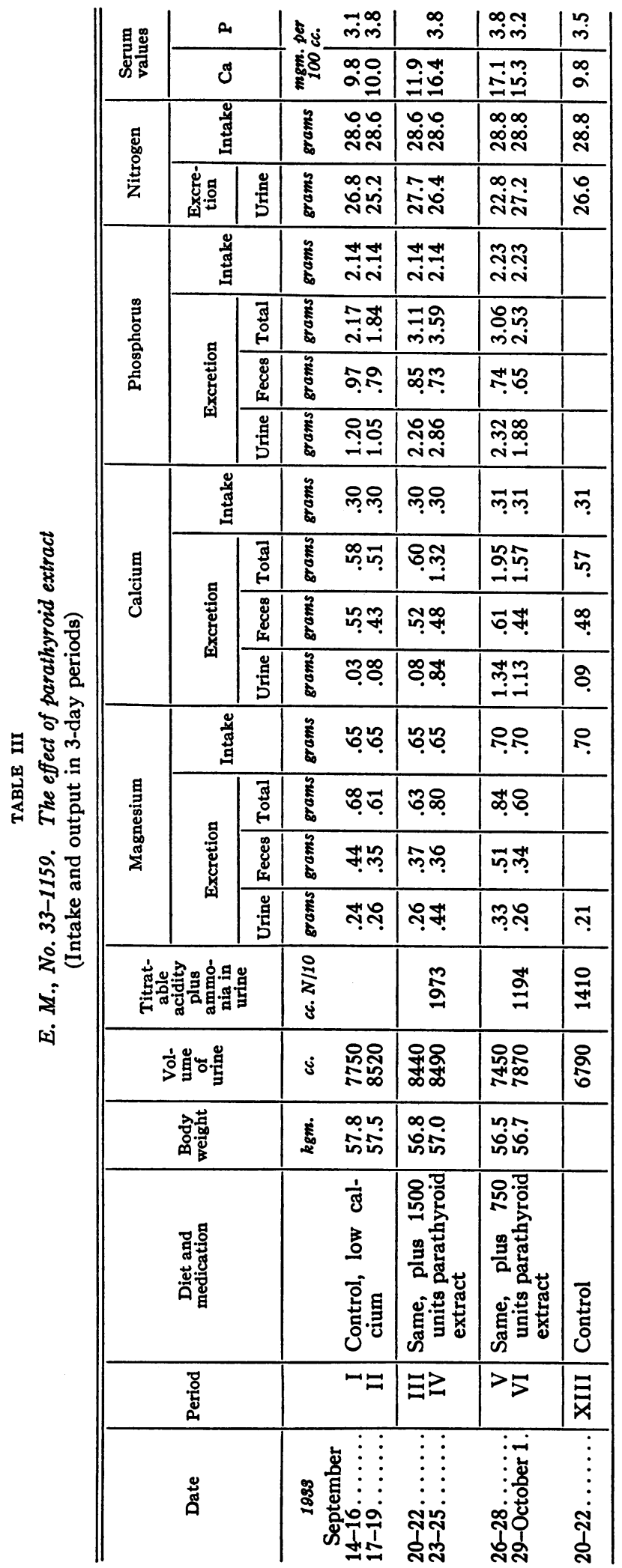


TABLE IV

Patient F. G., No. 35-69. Parathyroid adenoma. The effect of magnesium ingestion

(Intake and output in 3-day periods)

\begin{tabular}{|c|c|c|c|c|c|c|c|c|c|c|c|c|c|c|c|c|c|c|c|c|c|}
\hline \multirow{3}{*}{ Date } & \multirow{3}{*}{ riod } & \multirow{3}{*}{$\begin{array}{l}\text { Diet and } \\
\text { medication }\end{array}$} & \multirow{3}{*}{$\begin{array}{c}\text { Body } \\
\text { wt. }\end{array}$} & \multirow{3}{*}{$\begin{array}{c}\text { Vol- } \\
\text { ume } \\
\text { of } \\
\text { urine }\end{array}$} & \multirow{3}{*}{$\begin{array}{c}\text { Wet } \\
\text { weight } \\
\text { of } \\
\text { stools }\end{array}$} & \multirow{3}{*}{$\begin{array}{l}\text { Calcu- } \\
\text { lated } \\
\text { acid- } \\
\text { ity } \\
\text { of } \\
\text { intake }\end{array}$} & \multicolumn{4}{|c|}{ Magnesium } & \multicolumn{4}{|c|}{ Calcium } & \multicolumn{4}{|c|}{ Phosphorus } & \multicolumn{3}{|c|}{$\begin{array}{l}\text { Serum values } \\
\text { (fasting) }\end{array}$} \\
\hline & & & & & & & \multicolumn{3}{|c|}{ Excretion } & \multirow{2}{*}{$\underset{\text { take }}{\text { In- }}$} & \multicolumn{3}{|c|}{ Excretion } & \multirow{2}{*}{$\begin{array}{l}\text { In- } \\
\text { take }\end{array}$} & \multicolumn{3}{|c|}{ Excretion } & \multirow{2}{*}{$\begin{array}{l}\text { In- } \\
\text { take }\end{array}$} & \multirow{2}{*}{$\mathrm{Mg}$} & \multirow{2}{*}{$\mathrm{Ca}$} & \multirow{2}{*}{$\mathbf{P}$} \\
\hline & & & & & & & Urine & Feces & Total & & Urine & Feces & Total & & Urine & Feces & Total & & & & \\
\hline $\begin{array}{c}1985 \\
\text { January } \\
20-22 . . . \\
23-25 . \ldots\end{array}$ & I & $\begin{array}{l}\text { Moderate cal- } \\
\text { cium }\end{array}$ & kgm. & \begin{tabular}{|c|}
$c c$. \\
\\
6120 \\
5850
\end{tabular} & $\begin{array}{l}215 \\
210\end{array}$ & $\begin{array}{c}c c . \\
N / 10 \\
-10 \\
-10\end{array}$ & \begin{tabular}{c|} 
grams \\
.27 \\
.33
\end{tabular} & $\begin{array}{r}\text { grams } \\
\\
.30 \\
.29\end{array}$ & \begin{tabular}{r|} 
grams \\
.57 \\
.62
\end{tabular} & $\begin{array}{c}\text { grams } \\
.91 \\
.91\end{array}$ & \begin{tabular}{|c|} 
grams \\
\\
1.36 \\
1.45
\end{tabular} & \begin{tabular}{r|} 
grams \\
\\
1.13 \\
.99
\end{tabular} & \begin{tabular}{c|} 
grams \\
\\
2.49 \\
2.44
\end{tabular} & \begin{tabular}{l|} 
grams \\
\\
2.20 \\
2.20
\end{tabular} & $\begin{array}{c}\text { grams } \\
\\
2.92 \\
3.06\end{array}$ & $\begin{array}{r}\text { grams } \\
\\
.57 \\
.58\end{array}$ & $\begin{array}{c}\text { grams } \\
\\
3.49 \\
3.64\end{array}$ & $\begin{array}{l}\text { grams } \\
\\
3.74 \\
3.74 \\
\end{array}$ & $\begin{array}{l}2.9 \\
2.6\end{array}$ & $\begin{array}{l}15.5 \\
14.2\end{array}$ & 2.9 \\
\hline $\begin{array}{l}26-28 \ldots . \\
29-31 \ldots . \\
\text { February } \\
1-3 \ldots \ldots . \\
4-6 \ldots . .\end{array}$ & $\begin{array}{c}\text { III } \\
\text { IV } \\
\text { v } \\
\text { VI }\end{array}$ & $\begin{array}{l}\text { Same plus } 17 \\
\text { grams magne- } \\
\text { sium gluconate }\end{array}$ & 72.6 & \begin{tabular}{|l|}
5280 \\
5390 \\
4710 \\
6240
\end{tabular} & $\begin{array}{r}490 \\
1030 \\
\\
835 \\
985\end{array}$ & $\begin{array}{l}-2482 \\
-2482 \\
-2482 \\
-2482\end{array}$ & $\begin{array}{l}.23 \\
.45 \\
.44 \\
.60\end{array}$ & $\begin{array}{l}1.25 \\
3.12 \\
1.98 \\
2.52\end{array}$ & $\begin{array}{l}1.48 \\
3.57 \\
\\
2.42 \\
3.12\end{array}$ & $\begin{array}{l}3.91 \\
3.91\end{array}$ & $\begin{array}{l}1.24 \\
1.17 \\
1.14 \\
1.16\end{array}$ & $\begin{array}{l}1.39 \\
2.10\end{array}$ & $\begin{array}{l}2.40 \\
2.88\end{array}$ & $\begin{array}{l}2.20 \\
2.20\end{array}$ & $\begin{array}{l}2.72 \\
2.67\end{array}$ & $\begin{array}{r}.76 \\
1.08 \\
.73 \\
.88\end{array}$ & $\begin{array}{l}3.52 \\
3.75 \\
\\
3.45 \\
3.55\end{array}$ & $\begin{array}{l}3.74 \\
3.74\end{array}$ & $\begin{array}{l}2.4 \\
2.5\end{array}$ & $\begin{array}{l}14.1 \\
14.1\end{array}$ & 2.6 \\
\hline
\end{tabular}

PARA THYROIDACTOMT-MEBRUARY 8, 1935

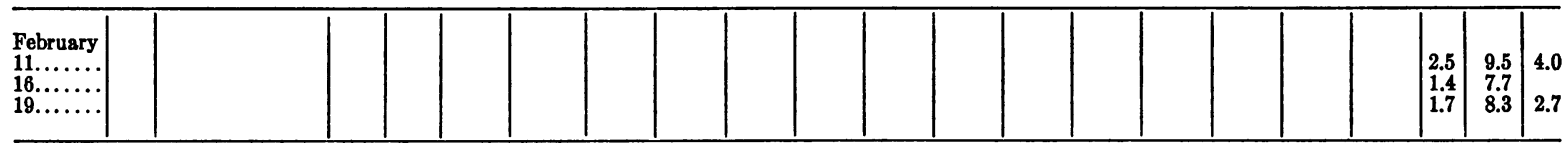

lation, it is of interest to see whether magnesium can be substituted for the great drain of calcium imposed on the bones by an overactive parathyroid adenoma.

Patient F. G., a woman of 41 years, was a typical case of markedly overactive parathyroid adenoma, with large, multiple bone cysts, a renal stone, and a quiescent duodenal ulcer. In the metabolic research routine she was purposely given a moderately high calcium diet, large enough to produce only a relatively slight calcium loss from the body. After the control periods, magnesium gluconate was added to the regime. If magnesium could substitute for calcium in the body metabolism, then the calcium excretion should be reduced by this addition. The data are collected in Table IV.

The calcium exchange in the control periods, with the very high values for urinary excretion, is characteristic of the disease. The addition of magnesium gluconate to the diet increased the total calcium output in three out of four periods. This increase was entirely due to fecal excretion, as there was a definite decrease in urinary elimination. The average increase in the feces of 560 $\mathrm{mgm}$. of calcium per period might be attributed to the cathartic effect of magnesium gluconate. However, two normal controls studied during three periods of constipation and four periods of diarrhea induced by cascara showed an average increase in weight of wet feces of 700 grams per period while the increase in fecal calcium excretion averaged but $50 \mathrm{mgm}$. per period (5). The increase in this case of hyperparathyroidism on magnesium ingestion is, therefore, ten times that found in these controls.

Magnesium was dramatically stored in this whole observation. Even in the control periods it was stored in amounts we have never observed elsewhere.

The phosphorus balance remained essentially unchanged. If the large magnesium retention had been stored 'as phosphate, a greater retention of phosphorus should have been present in the periods of magnesium ingestion. We are unable to explain this.

From these observations it is obvious that magnesium cannot be substituted for calcium excretion in the hyperparathyroid state. In fact, it increases the loss of calcium (average of 340 mgm. per period). It is possible, however, that the magnesium retention may be substituting for the great loss of calcium from the bones. Evidence for increased relative amounts of magnesium in bones in osteomalacia, rickets, etc., does exist in the literature, though the evidence is by no means unanimous $(6,7)$. The fact that in this case, with severe decalcification and large 
multiple bone cysts, there was a constant large positive magnesium balance; that there was a similar storage even on a very low magnesium intake in a case of steatorrhea with tetany $(8)$; and that in two normal controls on a low calcium intake (4) there was a slight reaction of the same nature, suggests that the calcium lost from the bones may be replaced by magnesium. Direct bone analyses are needed to investigate this.

\section{CONCLUSIONS}

From these observations several conclusions can be stated.

1. The magnesium excretion in the hyperparathyroid state is essentially at a normal level, and two of our three cases 'stored more magnesium than did the normal controls.

2. Correcting the hyperparathyroid condition is followed, however, by a temporary fall in magnesium excretion, particularly in the urine. This reduction is slight in comparison with total calcium reduction, but is greater than is to be expected from the ratio $\mathrm{Mg}: \mathrm{Ca}$ in the bones.

3. A few months after parathyroidectomy, the magnesium excretion returns toward the preoperative level, while calcium retention remains intense.

4. The administration of parathyroid extract temporarily raises urinary magnesium excretion to a degree which indicates that some is derived from soft tissue.

5. Magnesium excretion appears to be independent of changes in calcium intake in hyperparathyroidism.

6. The addition of magnesium gluconate to the diet does not relieve the drain upon body calcium due to hyperparathyroidism, as would the administration of calcium. The reverse is true, for increased magnesium ingestion increased calcium excretion.

7. Although magnesium is not substituted for calcium in the excretion during hyperparathyroidism, the storage of magnesium suggests that it may possibly substitute for calcium in the bones.

\section{CASE HISTORIES}

G. $M$. (C. P. Huntington Hosp. No. 32-599, P. B. B. H. No. 78536), male, was 13 years of age. Never a strong child, he had frequent "bilious" attacks. Three years before entrance he had severe erysipelas. He has never walked well since, and usually pulls himself upstairs with the aid of his hands. $\mathrm{He}$ has always had polydipsia, polyuria, and enuresis, particularly for the last eight months. He complained of pain in his back and increasing weakness and dyspnea. Two months before the present studies he went to the Harvard Dental School where a giant-cell tumor of the jaw was twice removed. The $\mathrm{x}$-ray disclosed a generalized osteoporosis without cysts and without renal calculi.

Physical examination reveals a very emaciated, poorly muscled, 'tall boy, with moderate beading of costochondral junctions. There is a palpable, soft, walnutsized mass above the left clavicle over which no bruit could be heard. The left clavicle is disarticulated, muscular development and coördination of movements are very poor. There is a nightly enuresis, unless he is awakened hourly. Laboratory data (not presented in the tables) include :

Basal metabolic rate: +10 per cent (Aub-DuBois).

Blood: Red blood cells-3,600,000; hemoglobin-65 per cent (Sahli standard 10.1 grams of hemoglobin per 100 cc.).

Urine: Specific gravity never above 1.011. Albumintrace. Sediment showed few granular casts and a moderate number of pus cells. Phenolsulphonphthalein test 35 per cent. Nonprotein nitrogen $39 \mathrm{mgm}$. per cent.

After a period of metabolic study the patient was transferred to the Peter Bent Brigham Hospital and on June 4, 1932, Dr. Homans removed a large parathyroid adenoma. This weighed 11.8 grams and histologically was composed predominantly of "Wasserhelle" cells. On June 6 the blood calcium had fallen to $9.0 \mathrm{mgm}$. per cent. On the sixth postoperative day the patient returned to the Huntington Hospital for continuation of his metabolic studies.

In the four subsequent years the patient has been essentially well.

A. R. (C. P. Huntington Hosp. No. 32-291; M. G. H. series, Case No. 8 ; path. No. $32-4330$ ), female, was 44 years of age. She felt perfectly well except that for the last five months she had pain in her right hip. At that time (March 1932), x-ray examination showed an extensive destructive process in the right ilium without evident decalcification of other bones. A right kidney stone was visible. At this time, before she had a medical consultation (March 7 to 16, 1932), she was given $1,000 \mathrm{r}$ units of $\mathrm{x}$-ray therapy over her pelvis. This resulted in permanent amenorrhea. On March 16 her serum calcium was $14.8 \mathrm{mgm}$. per cent, and her serum phosphorus was $1.7 \mathrm{mgm}$. per 'cent. On March 18 her calcium was $14.0 \mathrm{mgm}$. per cent, and her phosphorus was $1.5 \mathrm{mgm}$. per cent. She was admitted to the Collis $P$. Huntington Memorial Hospital on March 28, 1932, for metabolic studies. These were repeated in October and November, 1932. On December 2, 1932, she was operated upon at the Massachusetts General Hospital by Dr. Churchill and Dr. Cope, and a parathyroid adenoma of 
transition "Wasserhelle" type was removed. Between January 18 and February 17, 1933, she had further metabolic studies at the Huntington Hospital.

Subsequent course: she has been seen repeatedly and has felt perfectly well, though she has gained too much weight. She has had hot flashes and has not menstruated since the $\mathrm{x}$-ray treatment.

F. G. (C. P. Huntington Mem. Hosp. No. 35-69; P. B. B. H. No. 89994) was a married woman of 41 years of age. She had been operated upon for a ruptured gastric ulcer eight years ago and for the removal of a kidney stone four years ago. Since then she has had difficulty in walking because of pain in the legs and lower back. Nine months ago she fell on her back, and x-rays disclosed a generalized severe osteitis fibrosa cystica.

Physical examination showed nothing remarkable except marked pyorrhea, some tenderness over the tips of both tibiae, and abdominal scars.

Extensive laboratory studies showed normal results except that $\mathrm{x}$-ray showed many multilocular cysts, generalized osteoporosis, and a kidney stone. The urine showed consistent low specific gravity. The feces frequently had evidence of occult blood. Serum calcium level was repeatedly above $14 \mathrm{mgm}$. per cent, and phosphorus level below $2.2 \mathrm{mgm}$. per cent.

On February 8, 1935, an oxyphil type of parathyroid adenoma was removed by Dr. Zollinger and Dr. Cutler at the Peter Bent Brigham Hospital. This was promptly followed by a drop of serum calcium to $7.0 \mathrm{mgm}$. per cent, and serum phosphorus rose to $3.7 \mathrm{mgm}$. per cent. Since then there has been great improvement. X-ray shows the bone cysts are filling in, and except for an increase in weight and a lowered basal metabolic rate the patient finds herself very 'well.

\section{BIBLIOGRAPHY}

1. Greenwald, I., and Gross, J., The effect of thyroparathyroidectomy in dogs upon the excretion of calcium, phosphorus, and magnesium. J. Biol. Chem., 1925, 66, 185.

2. Greenwald, I., and Gross, J., The effect of long continued administration of parathyroid extract upon the excretion of phosphorus and calcium. J. Biol. Chem., 1926, 68, 325.

3. Bulger, H. A., and Gausmann, F., Magnesium metabolism in hyperparathyroidism. J. Clin. Invest., 1933, $12,1135$.

4. Tibbetts, D. M., and Aub, J. C., Magnesium metabolism in health and disease. I. The magnesium and calcium excretion of normal individuals, also the effects of magnesium, chloride, and phosphate ions. J. Clin. Invest., 1937, 16, 491.

5. Aub, J. C., Tibbetts, D. M., and McLean, R., Studies of calcium and phosphorus metabolism. XXII. The influence of parathyroid hormone, urea, sodium chloride, fat, and of intestinal activity upon calcium balance. J. Nutrition, 1937, 13, 635.

6. McCrudden, F. H., Metabolism in Diseases of the Bones and Joints. In Endocrinology and Metabolism. Vol. IV. D. Appleton and Co., New York, 1922, p. 741.

7. Euler, H. von, and Rydbom, M., Uber den Einfluss von Magnesiumsalzen auf Knochenbildung und Rachitis. I. Biochem. Ztschr., 1931, 241, 14.

8. Tibbetts, D. M., and Aub, J. C., Magnesium metabolism in health and disease. III. In exophthalmic goiter, basophilic adenoma, Addison's disease, and steatorrhea. J. Clin. Invest., 1937, 16, 511. 